\title{
Selecting Criteria for Assessing "Environmentally-Friendly" Material Options in Construction: Part II
}

\author{
Robert Bucoń $^{1}$ and Agata Czarnigowska ${ }^{2}$ \\ ${ }^{1}$ Dpt. Of Construction Methods and Management, Faculty of Civil Engineering and Architecture, \\ Politechnika Lubelska, Nadbystrzycka 40, 20-618 Lublin, Poland, r.bucon@pollub.pl \\ ${ }^{2}$ Dpt. Of Construction Methods and Management, Faculty of Civil Engineering and Architecture, \\ Politechnika Lubelska, Nadbystrzycka 40, 20-618 Lublin, Poland, a.czarnigowska@pollub.pl
}

\begin{abstract}
One of the design team's tasks is assuring that their project has a low negative impact on the environment. This comes from regulations as well as expectations of direct benefits (reduction of operating cost, the project's improved image in the eyes of the public, etc.). To fulfill this task, one needs to define criteria for assessing the design options. These are to correspond to the individual qualities of the project, and they should be significant and possible to assess. The paper, divided into two parts, presents a review of the literature concerning the criteria for the assessment of design solutions defined as "green" or "environmentally friendly". Part I presented the method of the analysis and investigates into the number and type of criteria adopted in the sample of papers being the object of analysis. This part focuses on the ways of defining criteria values, weights, and methods of multicriteria assessment.
\end{abstract}

Keywords: Sustainable Construction, Component Selection, LCA, Literature Review.

\section{Introduction}

In the face of resource depletion and the likely suffocation with its own refuse within decades, humanity is dragged towards a sustainable economy and, in particular, sustainable construction (Goh, Chong, Jack and Mohd Faris, 2020). One of the aspects of construction sustainability is reducing the project's and the resulting built facility's impact on the environment. This impact is typically assessed in the course of a Life Cycle Analysis (LCA) (Ortiz, Castells and Sonnemann, 2009). The idea of LCA evolved into many methodologies that share the element of assessing the consequences of using particular construction materials in the building's fabric. However, even in this narrow aspect, the analyses' scope, criteria, and measures are not identical (Park, Yoon and Kim, 2017). The standards and methodologies evolve (Allacker, Mathieux, Pennington and Pant, 2017). Due to the proliferation of LCA methodologies, the comparability of information on products' environmental qualities becomes an issue (European Union, 2013).

This paper is a second part of the review of the most recent literature on selecting the "environmentally friendly" material and component options in construction. The authors discuss a sample of papers devoted to assessing the sustainability of alternative solutions (materials, material supply chains, component design) and optimizing construction components, focusing on the ways of defining criteria values, the criteria's relative importance, and selecting the methods of multicriteria assessment. 


\section{Materials and Methods}

The sources' approach to the life cycle phases was juxtaposed to the life cycle phases used in LCA and adopted for Environmental Product Declarations (EPDs). The "environmentally friendly" aspects were considered only those covered by the scope of environmental impacts, aspects of resource use, and generation of waste as defined in EPDs prepared according to EN 15804:2012. The query was limited to one database (Web of Science), publications from the years 2016-2020, and a particular structure of search terms, as presented in Part I. The selection was manually refined. The final sample comprised 43 publications. The sample was analyzed in terms of aspects of sustainability covered by the analysis, life cycle stages considered, sources of input, and mathematical methods used for selecting the best option (if applicable).

\section{Results and Discussion}

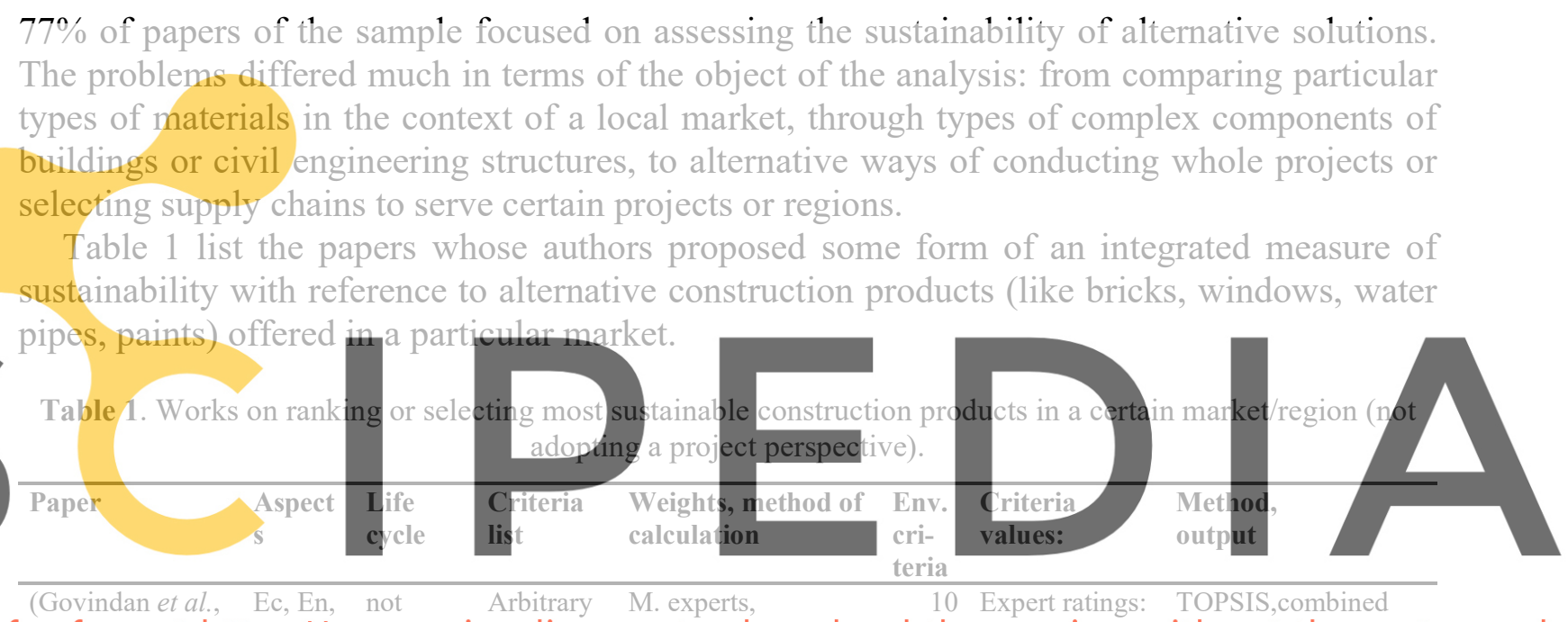

(Govindan etal., Ec, En, not Arbitrary M. experts, 10 Expert ratings: TOPSIS,combined

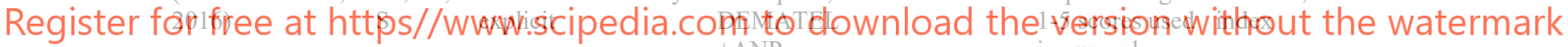

\begin{tabular}{|c|c|c|c|c|c|c|c|}
\hline $\begin{array}{l}\text { (Bissoli-Dalvi et } \\
\text { al., 2016) }\end{array}$ & En & A-D & Arbitrary & 1 expert, ISMAS & 7 & $\begin{array}{l}\text { Expert: ratings } \\
\text { in 3-ievel scale }\end{array}$ & $\begin{array}{l}\text { ISMAS, combined } \\
\text { index }\end{array}$ \\
\hline (Roy et al., 2019) & $\begin{array}{l}\text { Ec, } \\
\text { En,S }\end{array}$ & $\begin{array}{l}\text { not } \\
\text { explicit }\end{array}$ & Arbitrary & $\begin{array}{l}\text { M. experts, fuzzy } \\
\text { pairwise } \\
\text { comparisons, linear } \\
\text { programming; } \\
\text { sensitivity analysis }\end{array}$ & 4 & $\begin{array}{l}\text { M. experts, } \\
\text { Fuzzy ratings }\end{array}$ & $\begin{array}{l}\text { IVIF-CODAS. } \\
\text { combined index }\end{array}$ \\
\hline $\begin{array}{l}\text { (Zhang et al., } \\
\text { 2017) }\end{array}$ & $\begin{array}{l}\text { T, Ec, } \\
\text { En }\end{array}$ & $\begin{array}{l}\text { A1-A3+ } \\
\text { disposal }\end{array}$ & Arbitrary & $\begin{array}{l}\text { M. experts, } \\
\text { DEMATEL } \\
\text { +ANP; sensitivity } \\
\text { analysis }\end{array}$ & 5 & $\begin{array}{l}\text { Expert ratings } \\
\text { in scale } 1-5 \text { in } \\
\text { example }\end{array}$ & $\begin{array}{l}\text { G-TOPSIS, combined } \\
\text { index }\end{array}$ \\
\hline $\begin{array}{l}\text { (Mathiyazhagan } \\
\text { et al., 2019) }\end{array}$ & $\begin{array}{l}\text { Ec, } \\
\text { En,S }\end{array}$ & $\begin{array}{l}\text { not } \\
\text { explicit }\end{array}$ & $\begin{array}{l}\text { team of } \\
\text { experts } \\
\text { /literature }\end{array}$ & $\begin{array}{l}\text { M. experts, } \\
\text { integrated by } \\
\text { averaging; BWM }\end{array}$ & 9 & Expert ratings & $\begin{array}{l}\text { fuzzy TOPSIS, } \\
\text { combined index }\end{array}$ \\
\hline $\begin{array}{l}\text { (Rochikashvili } \\
\text { and Bongaerts, } \\
\text { 2016) }\end{array}$ & $\begin{array}{l}\text { T, Ec, } \\
\text { En, S }\end{array}$ & $\begin{array}{l}\text { not } \\
\text { explicit }\end{array}$ & Arbitrary & M. experts, ANP & 1 & $\begin{array}{l}\text { Expert } \\
\text { pairwise } \\
\text { comparisons }\end{array}$ & $\begin{array}{l}\text { ANP, combined } \\
\text { index }\end{array}$ \\
\hline $\begin{array}{l}\text { (Maiolo et al., } \\
\text { 2018) }\end{array}$ & $\begin{array}{l}\text { T, Ec, } \\
\text { En }\end{array}$ & A1-A3 & $\begin{array}{l}\text { LCA } \\
\text { (Impact } \\
2002+) \\
\end{array}$ & $\begin{array}{l}\text { Acc. to Impact } \\
2002+\end{array}$ & $\mathrm{n} / \mathrm{a}$ & $\begin{array}{l}\text { databases \& } \\
\text { calculations }\end{array}$ & $\begin{array}{l}\text { multiplying two } \\
\text { indices, combined } \\
\text { index }\end{array}$ \\
\hline
\end{tabular}


A common feature of these papers is analyzing the options in abstraction from projects they might be used for. In this group, all papers but two presented analyses from the perspective of developing countries and based on criteria values rated by experts (though some methods were applicable also for measurable criteria).

For instance, Govindan, Madan Shankar, \& Kannan (2016) used DEMATEL combined with ANP to establish the set of criteria and their relationships on the basis of opinions of multiple experts, and then TOPSIS for the assessment of options. They illustrated their approach on the example of selecting the "most sustainable" type of brick as perceived by the construction professionals (clients, architects, contractors) in UAE market. In this case, all 10 criteria related to the environmental impact would be possible to express as quantitative measures established in the course of LCA, but the authors were vague about the way of the source of their values; judging by the presentation of illustrative example, the values were expresses as arbitrary scores in a 1-5 scale. Bissoli-Dalvi et al. (2016) compared the sustainability of different types of windows used in Brazilian housing using an original ISMAS method. Due to the lack of databases of environmental product properties, they resorted to an individual set of "green" criteria and expressed their values by ratings in a unified 3-point scale (-1 for "worse than average requirements", 0 for "standard practice", 1 for qualities considered "better than acceptable"). The ratings were then treated as additive scores that, after being weighted, were combined into a quantitative index for direct comparison of options.

Rochikashvili and Bongaerts (2016) aimed at conducting the comparison of products to

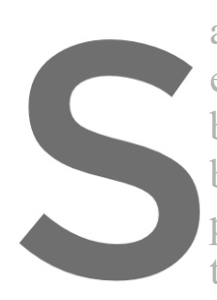
appeal to non-experts. For environmental impact benefits, costs, opporturit belonged to the latter. particular soil condition the market using Impact 2002+ methodology,
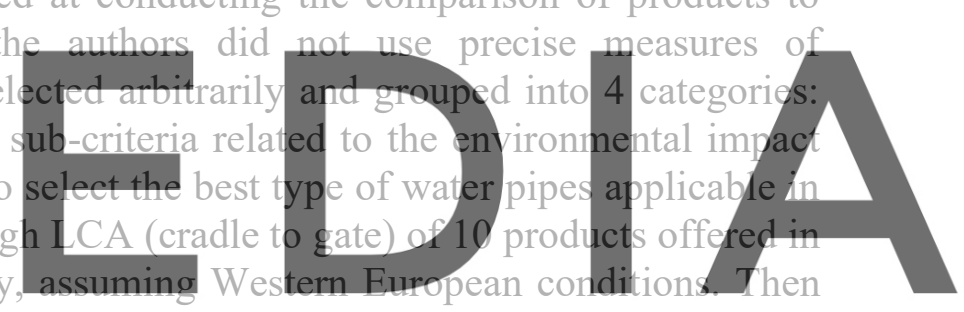
they combined its overall measure of environmental profile with the coefficient capturing

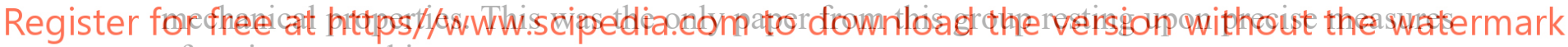
of environmental impact.

Shipping large quantities of materials, as required in the case of construction projects, generates high cost, consumes fossil fuels and pollutes the natural environment. Therefore, the A2 and A4 phases of the lifecycle are a natural focus of construction sustainability researchers. In the sample, two papers were devoted to analyzing supply chains. Ahmadian et al. (2017) considered different sources, levels of prefabrication, modes and distances of transport. Designing their BIM-based supply chain management system, they argued that the environmental criteria should be project-specific and might be defined by experts, though they should refer at least to the material production, transport to the site and installation phase, as well as they should consider the potential of re-use and recycling. Basti (2018) analyzed the problem managing large quantities of earthquake debris, a current problem of Italian regions struck by natural disasters. He focused on environmental issues of deconstruction, transport, depositing, and reusing this material, as well as on constraints resulting from regulations. This was done not in a "per project" approach, but from the point of municipal strategies that consider the network of local enterprises to be engaged in the process, restrictions on road use for heavy transport, selection of means of transport with regard to location of debris processing, landfilling and reuse areas. 
The biggest part of the sample of papers dealt with the problem of comparing alternative products of complex components from the perspective of a project (particular location, particular quantities, individual constraints due to the design of the building/civil engineering structure - Table 2).

Table 2. Works on comparing options of building components assuming perspective of a particular project.

\begin{tabular}{|c|c|c|c|c|c|c|c|}
\hline Paper & $\begin{array}{l}\text { Aspect } \\
\text { s }\end{array}$ & $\begin{array}{l}\text { Life } \\
\text { cycle }\end{array}$ & Criteria list & $\begin{array}{l}\text { Weights, method } \\
\text { of calculation }\end{array}$ & $\begin{array}{l}\text { Env. } \\
\text { cri- } \\
\text { teria } \\
\end{array}$ & $\begin{array}{l}\text { Criteria } \\
\text { values: }\end{array}$ & $\begin{array}{l}\text { Method } \\
\text { output }\end{array}$ \\
\hline $\begin{array}{l}\text { (Ananin et al., } \\
\text { 2018) }\end{array}$ & En & A1-A3 & Arbitrary & - & 1 & $\begin{array}{l}\text { databases \& } \\
\text { calculations }\end{array}$ & $\begin{array}{l}\text { ranking acc. to energy } \\
\text { embodied in materials }\end{array}$ \\
\hline $\begin{array}{l}\text { (Gomez-Soberon } \\
\text { et al., 2016) }\end{array}$ & En & A4-C? & Arbitrary & - & 1 & $\begin{array}{l}\text { databases \& } \\
\text { calculations }\end{array}$ & $\begin{array}{l}\text { calculation of the } \\
\text { quantity of } 5 \text { types of } \\
\text { waste for each option }\end{array}$ \\
\hline $\begin{array}{l}\text { (Potkany et al., } \\
\text { 2018) }\end{array}$ & Ec, En & A1-A3 & LCA (EPD) & - & 6 & $\begin{array}{l}\text { databases \& } \\
\text { calculations }\end{array}$ & $\begin{array}{l}\text { calculation } \\
\text { of a set of measures } \\
\text { for each option }\end{array}$ \\
\hline $\begin{array}{l}\text { (Svajlenka and } \\
\text { Kozlovska, 2018) }\end{array}$ & $\mathrm{Ec}, \mathrm{En}$ & $\mathrm{A} 1-\mathrm{A} 3$ & LCA & - & 3 & $\begin{array}{l}\text { databases \& } \\
\text { calculations }\end{array}$ & $\begin{array}{l}\text { calculation } \\
\text { of a set of measures } \\
\text { for each option }\end{array}$ \\
\hline $\begin{array}{l}\text { (Hassan and } \\
\text { Johansson, 2018) }\end{array}$ & $\begin{array}{l}\text { T, Ec, } \\
\text { En }\end{array}$ & A1-A3? & Arbitrary & - & 1 & $\begin{array}{l}\text { databases \& } \\
\text { calculations }\end{array}$ & $\begin{array}{l}\text { calculation } \\
\text { of a set of measures } \\
\text { for each option }\end{array}$ \\
\hline $\begin{array}{l}\text { (Al-Nassar et al., } \\
\text { 2016) }\end{array}$ & $\begin{array}{l}\text { Ec, En, } \\
\text { S }\end{array}$ & $\mathrm{A}-\mathrm{C}$ & LCA & $\begin{array}{l}\text { Arbitrary; } \\
\text { sensitivity analysis }\end{array}$ & 8 & $\begin{array}{l}\text { databases \& } \\
\text { calculations }\end{array}$ & $\begin{array}{l}\text { weighted sum } \\
\text { combined index }\end{array}$ \\
\hline $\begin{array}{l}\text { (Chen et al., } \\
\text { 2019) }\end{array}$ & $\begin{array}{l}\text { T,Ec, } \\
\text { En, S }\end{array}$ & $\begin{array}{l}\text { not } \\
\text { explicit }\end{array}$ & Expert: & M. experts & 5 & M. experts & $\begin{array}{l}\text { ELECTRE III } \\
\text { combined index }\end{array}$ \\
\hline $\begin{array}{l}\text { (Casanovas- } \\
\text { Rubio et al., } \\
\text { 2019) }\end{array}$ & $\begin{array}{l}\text { Ec, En, } \\
\text { S }\end{array}$ & & & $\begin{array}{l}\text { T. of expert } \\
\text { AHP; } \\
\text { sensitivity a }\end{array}$ & 5 & tabase & MIVES \\
\hline $\begin{array}{l}\text { (Alberti et al., } \\
\text { 2018) }\end{array}$ & $\begin{array}{l}\text { Ec, En, } \\
\text { S }\end{array}$ & $A-B$ & Experts & $\begin{array}{l}\text { Arbitiary } \\
\text { (literature); }\end{array}$ & & $\begin{array}{l}\text { databases \& } \\
\text { calculations }\end{array}$ & $\begin{array}{l}\text { MIVES } \\
\text { combined index }\end{array}$ \\
\hline
\end{tabular}

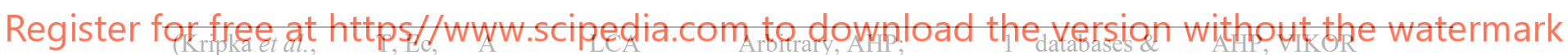

\begin{tabular}{|c|c|c|c|c|c|c|c|}
\hline 2019) & En, S & & (selected) & sens analysis & & calculations & combined index \\
\hline $\begin{array}{l}\text { (Kumanayake } \\
\text { and Luo, 2017) }\end{array}$ & Ec, En & $\mathrm{A}-\mathrm{C}$ & $\begin{array}{l}\text { LCA } \\
\text { (selected) }\end{array}$ & not decided yet & 1 & $\begin{array}{l}\text { databases \& } \\
\text { calculations }\end{array}$ & $\begin{array}{l}\text { not decided yet } \\
\text { combined index }\end{array}$ \\
\hline $\begin{array}{l}\text { (Sarkkinen et al., } \\
\text { 2019) }\end{array}$ & $\begin{array}{l}\text { T, Ec, } \\
\text { En,S }\end{array}$ & $\begin{array}{l}\text { not } \\
\text { explicit }\end{array}$ & LCA & $\begin{array}{l}\text { M. experts, AHP } \\
\text { (geometric mean); } \\
\text { sensitivity analysis }\end{array}$ & 2 & $\begin{array}{l}\text { databases \& } \\
\text { calculations }\end{array}$ & $\begin{array}{l}\text { AHP } \\
\text { combined index }\end{array}$ \\
\hline $\begin{array}{l}\text { (J Santos et al., } \\
\text { 2019) }\end{array}$ & $\begin{array}{l}\text { Ec, En, } \\
S\end{array}$ & $\mathrm{~A}-\mathrm{C}$ & $\begin{array}{l}\text { Arbitrary } \\
\text { (selection } \\
\text { justified) } \\
\end{array}$ & $\begin{array}{l}3 \text { approaches; } \\
\text { sensitivity analysis }\end{array}$ & 10 & $\begin{array}{l}\text { databases \& } \\
\text { calculations }\end{array}$ & $\begin{array}{l}\text { PROMETHEE II } \\
\text { combined index }\end{array}$ \\
\hline $\begin{array}{l}\text { (Joao Santos et } \\
\text { al., 2017) }\end{array}$ & Ec, En & A-C & LCA & $\begin{array}{l}\text { Arbitrary (as in } \\
\text { BEES); sensitivity } \\
\text { analysis }\end{array}$ & 8 & $\begin{array}{l}\text { databases \& } \\
\text { calculations }\end{array}$ & $\begin{array}{l}\text { TOPSIS } \\
\text { combined index }\end{array}$ \\
\hline $\begin{array}{l}\text { (Zheng et al., } \\
\text { 2019) }\end{array}$ & $\begin{array}{l}\text { Ec, } \\
\text { En,S }\end{array}$ & A-B & LCA & $\begin{array}{l}\text { M. experts, AHP } \\
\text { (geometric mean); } \\
\text { sensitivity analysis }\end{array}$ & 5 & $\begin{array}{l}\text { databases \& } \\
\text { calculations }\end{array}$ & $\begin{array}{l}\text { VIKOR } \\
\text { combined index }\end{array}$ \\
\hline $\begin{array}{l}\text { (Pavlovskis et al. } \\
\text { 2016) }\end{array}$ & $\begin{array}{l}\text { T, Ec, } \\
\text { En }\end{array}$ & $\mathrm{A}-\mathrm{C}$ & Arbitrary & $\begin{array}{l}\text { M. experts } \\
\text { WASPAS-G for } \\
\text { aggregation }\end{array}$ & 5 & M. experts & $\begin{array}{l}\text { WASPAS-G, } \\
\text { combined index; } \\
\text { Compared with } \\
\text { results of o. methods }\end{array}$ \\
\hline
\end{tabular}

Five works produced sustainability measures without combining them into overall scores 
(less convenient for comparison, but not affected by subjectivity in normalizing criteria values and setting weights). Among them, two papers considered a sole measure of the environmental impact. Among them, two papers considered sole measures of environmental impact: Ananin et al. (2018) looked for the best type for walls of a residential building in Russia with the lowest energy embodied in wall materials, while Gomez-Soberon et al. (2016) compared 3 options of floors according to the type and quantity of waste generated by replacement.

As the number of factors worth considering in the assessment may be large, some generalized measures to facilitate a clear distinction between options may be useful. 11 papers presented such measures. Among them, Chen et al. (2019) presented an interesting problem of designing components to the liking of various stakeholders by using Quality Function Deployment and ELECTRE III. They proposed a new group decision making method and illustrated its use on the example of selecting flooring for office space. With this approach, the set of criteria was individually defined for each case, expressing the stakeholders' point of view.

Casanovas-Rubio et al. (2019) assessed sustainability of trenching methods. Their method, MIVES, normalizes criteria scores by utility functions based on relative preferences expressed by experts. The values of criteria were expressed as precise numbers (e.g. water consumption in $\mathrm{dm}^{3}$ per $1 \mathrm{~m}$ of trench) or as scores (if the effort to estimate the precise measure was considered too great; however, justification for calculating the scores was provided). The analysis produced a single measure, Sustainability Index for Trenches, to compare the options. Alberti et al. (2018) used the same method to assess sustainability of two options of a structural component, namely

reinforcement. Intere 3 years of use in the Santos et al. (201 designs. The tool allows as found by the authors in a surve

impact were measurable, clearly defined in the literature, with the methods of calculation or

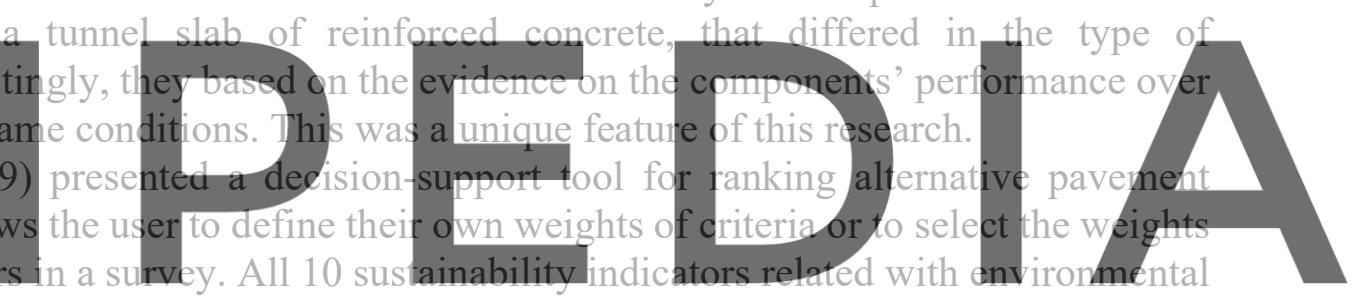

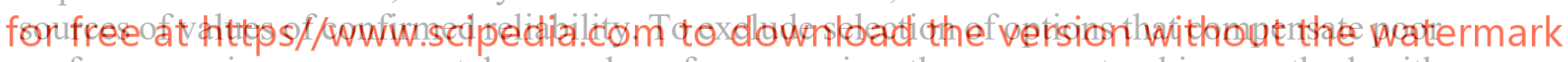
performance in some aspect by good performance in others, an outranking method with threshold values was selected as the core of the decision support tool. Out of the sample of papers, this one was considered to present the most convincing line of reasoning for selection of criteria (though the authors direct the reader to their subsequent publications for details) and methods for the ranking of options.

The remaining papers (not listed in Table 2) were not devoted to assessing predefined component options, but to solving multicriteria design problems. BuHamdan et al. (2019) presented a simulation model built to assess effects of combined design changes in a number of components (the size of glazed area, type of windows and thermal resistance of envelope) on the building's cost, measures of environmental impact in the construction, operation and demolition phase. Marti, Garcia-Segura and Yepes (2016) constructed an automated design optimization tool that prompts the best beam profile, concrete class and contents of prestressing and reinforcing steel of a prefabricated U-beam used in bridge construction. The model produces solutions that satisfy structural requirements at minimum cost and embodied energy in phase A of the lifecycle. 


\section{Summary and Conclusions}

Values of the criteria related to the environmental impact were either calculated or rated arbitrarily by experts, in the latter case using a variety of rating scales or in the course pairwise comparisons. Among 35 papers that compared/ranked options or aimed at finding an optimal solution, a dependence was observed ( $p$-value in $\chi^{2}$ test of 0,00124$)$ between the location of the object of analysis and the authors' method to define the criteria values (Figure 1). This observation is rather obvious: the geographical coverage of construction products' life cycle inventory databases is only slowly expanded on South America, Africa, and Asia.

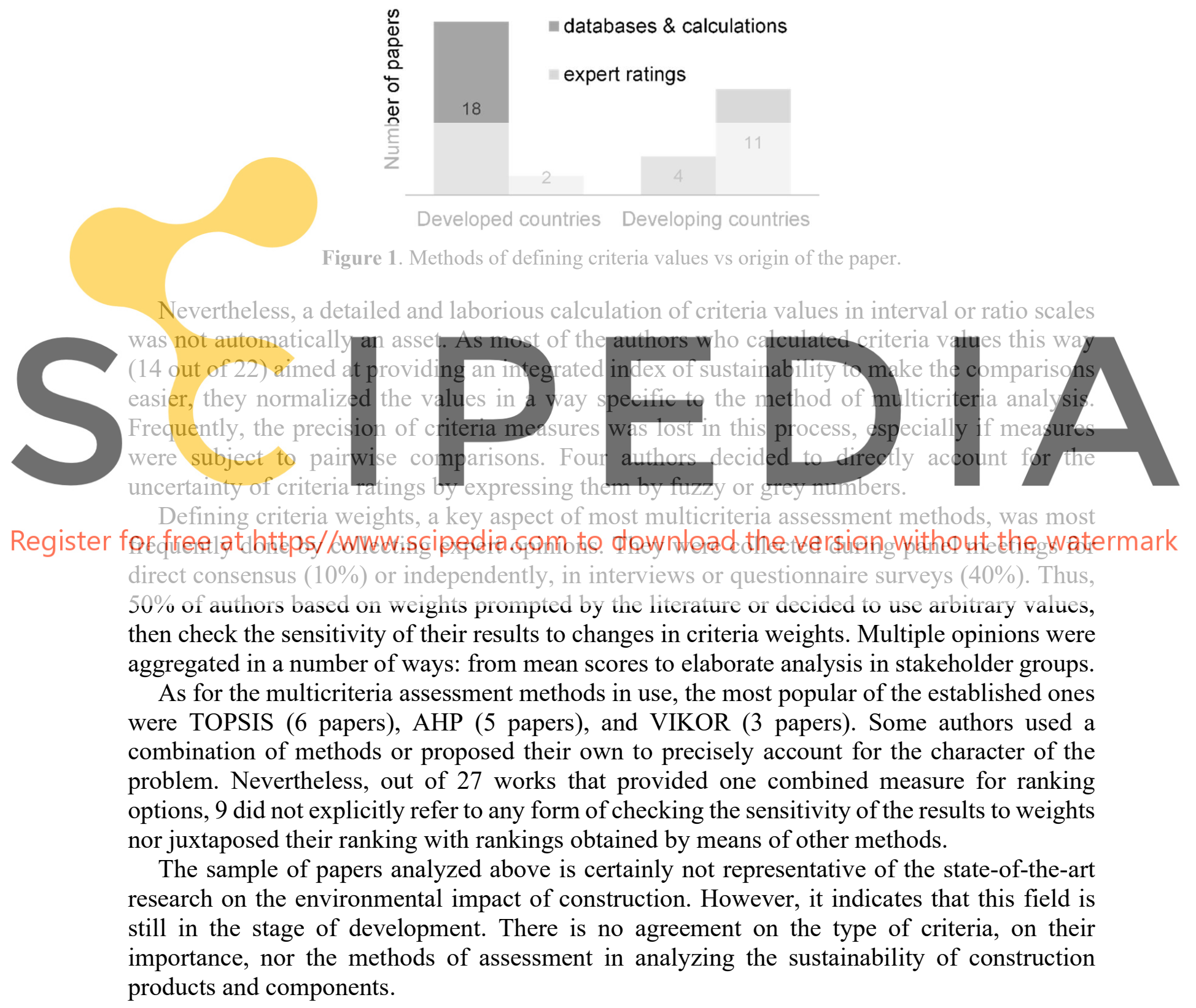




\section{Acknowledgements}

The work was funded by the Polish Ministry of Science and Higher Education ILT 63. The authors gratefully acknowledge the support.

\section{ORCID}

Robert Bucoń: https://orcid.org/0000-0002-9397-639X

Agata Czarnigowska: https://orcid.org/0000-0003-3715-3521

\section{References}

Ahmadian, A. F. F., Rashidi, T. H., Akbarnezhad, A. and Waller, S. T. (2017). BIM-enabled sustainability assessment of material supply decisions. Engineering, Construction and Architectural Management, 24(4), 668-695. doi: 10.1108/ECAM-12-2015-0193

Al-Nassar, F., Ruparathna, R., Chhipi-Shrestha, G., Haider, H., Hewage, K. and Sadiq, R. (2016). Sustainability assessment framework for low rise commercial buildings: life cycle impact index-based approach. Clean Technologies and Environmental Policy, 18(8, SI), 2579-2590. doi: 10.1007/s10098-016-1168-1

Alberti, M. G., Galvez, J. C., Enfedaque, A., Carmona, A., Valverde, C. and Pardo, G. (2018). Use of Steel and Polyolefin Fibres in the La Canda Tunnels: Applying MIVES for Assessing Sustainability Evaluation. Sustainability (Switzerland), 10(12). doi: 10.3390/su10124765

Allacker, K., Mathieux, F., Pennington, D. and Pant, R. (2017). The search for an appropriate end-of-life formula for the purpose of the European Commission Environmental Footprint initiative. International Journal of Life Cycle Assessment, 22(9), 1441-1458. doi: 10.1007/s11367-016-1244-0

Ananin, M., Perfilyeva, N., Vedishcheva, I. and Vatin, N. (2018). Investigation of different materials usage expediency for a low-rise public building from the energy efficiency standpoint. IOP Conference Series: Materials Science and En

Basti, A. (2018). Sustaina
impact assessment. De

Bissoli-Dalvi, M., Nico-Rod (2016). The sustainability

BuHamdan, S., Alwisy, A., Barkokebas, B., Bouferguene,

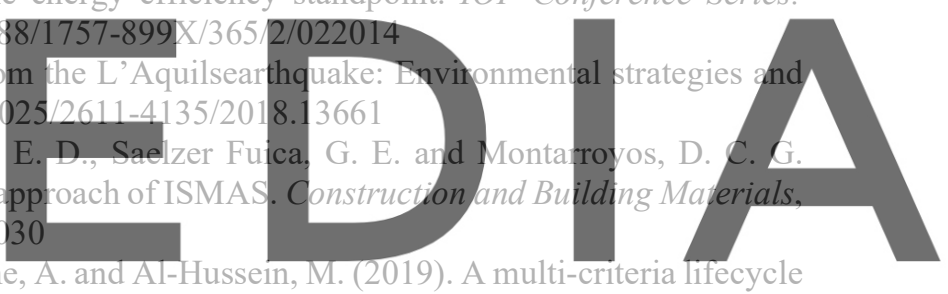
assessment framework for evaluating building systems design. Journal of Building Engineering, 23, 388-402.

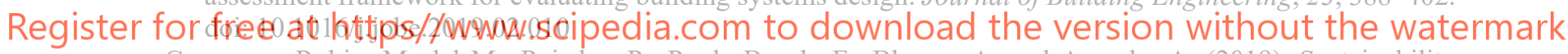

Casanovas-Rubio, M. del M., Pujadas, P., Pardo-Bosch, F., Blanco, A. and Aguado, A. (2019). Sustainability assessment of trenches including the new eco-trench: A multi-criteria decision-making tool. Journal of Cleaner Production, 238. doi: 10.1016/j.jclepro.2019.117957

Chen, Z.-S., Martínez, L., Chang, J.-P., Wang, X.-J., Xionge, S.-H. and Chin, K.-S. (2019). Sustainable building material selection: A QFD- and ELECTRE III-embedded hybrid MCGDM approach with consensus building. Engineering Applications of Artificial Intelligence, 85(December 2018), 783-807. doi: 10.1016/j.engappai.2019.08.006

European Union. (2013). Council Directive 2013/59/Euratom. In Official Journal of the European Union (Vol. 56, Issue L 124). doi: 10.3000/19770677.L_2013.124.eng

Goh, C. S., Chong, H.-Y., Jack, L. and Mohd Faris, A. F. (2020). Revisiting triple bottom line within the context of sustainable construction: A systematic review. Journal of Cleaner Production, 252, 119884. doi: 10.1016/J.JCLEPRO.2019.119884

Gomez-Soberon, J. M., Gomez-Soberon, M. C., Saldana-Marquez, H., Gamez-Garcia, D. C., Arredondo-Rea, S. P. and Corral-Higuera, R. (2016). Comparative by simulating the eventual waste generation of building indoor pavements construction. 2016 World Congress on Sustainable Technologies, WCST, 117-121.

Govindan, K., Madan Shankar, K. and Kannan, D. (2016). Sustainable material selection for construction industry - A hybrid multi criteria decision making approach. Renewable and Sustainable Energy Reviews, 55, 12741288. doi: 10.1016/j.rser.2015.07.100

Hassan, O. A. B. and Johansson, C. (2018). Glued laminated timber and steel beams: A comparative study of structural design, economic and environmental consequences. Journal of Engineering, Design and Technology, 
16(3), 398-417. doi: 10.1108/JEDT-12-2017-0130

Kripka, M., Yepes, V. and Milani, C. J. (2019). Selection of sustainable short-span bridge design in Brazil. Sustainability (Switzerland), 11(5). doi: 10.3390/su11051307

Kumanayake, R. and Luo, H. (2017). Development of an automated tool for buildings' sustainability assessment in early design stage. Procedia Engineering, 196, 903-910. doi: 10.1016/j.proeng.2017.08.023

Maiolo, M., Capano, G., Carini, M. and Pantusa, D. (2018). Sustainability criteria for the selection of water supply pipeline. Cogent Engineering, 5(1). doi: 10.1080/23311916.2018.1491777

Marti, J. V, Garcia-Segura, T. and Yepes, V. (2016). Structural design of precast-prestressed concrete U-beam road bridges based on embodied energy. Journal of Cleaner Production, 120, 231-240. doi: 10.1016/j.jclepro.2016.02.024

Mathiyazhagan, K., Gnanavelbabu, A. and Prabhuraj, B. L. (2019). A sustainable assessment model for material selection in construction industries perspective using hybrid MCDM approaches. Journal of Advances in Management Research, 16(2), 234-259. doi: 10.1108/JAMR-09-2018-0085

Ortiz, O., Castells, F. and Sonnemann, G. (2009). Sustainability in the construction industry: A review of recent developments based on LCA. Construction and Building Materials, 23(1), 28-39. doi: 10.1016/J.CONBUILDMAT.2007.11.012

Park, J., Yoon, J. and Kim, K.-H. (2017). Critical review of the material criteria of building sustainability assessment tools. Sustainability (Switzerland), 9(2). doi: 10.3390/su9020186

Pavlovskis, M., Antucheviciene, J. and Migilinskas, D. (2016). Application of MCDM and BIM for Evaluation of Asset Redevelopment Solutions. Studies in Informatics and Control, 25(3), 293-302.

Potkany, M., Gejdos, M. and Debnar, M. (2018). Sustainable Innovation Approach for Wood Quality Evaluation in Green Business. Sustainability (Switzerland), 10(9). doi: 10.3390/su10092984

Rochikashvili, M. and Bongaerts, J. C. (2016). Multi-criteria decision-making for sustainable wall paints and coatings using Analytic Hierarchy Process. Energy Procedia, 96, 923-933. doi: 10.1016/j.egypro.2016.09.167

Roy, J., Das, S., Kar, S. and Pamučar, D. (2019). An extension of the CODAS approach using interval-valued intuitionistic fuzzy set for sustainable material selection in construction projects with incomplete weight information. Symmetry,

Santos, J, Bressi, S., Cerezo, system for road pavement

Santos, Joao, Elintsch, construction and mang
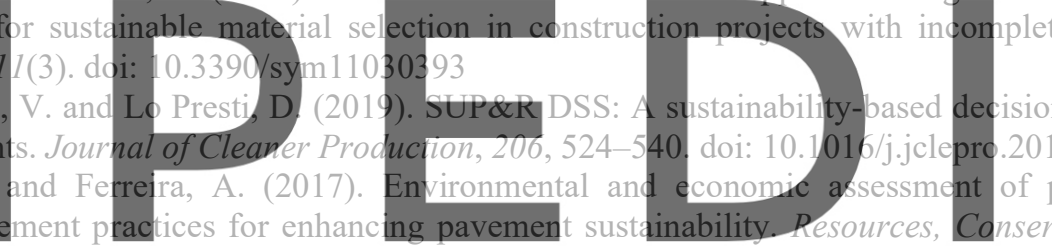

Recycling, 116, 15-31. doi: 10.1016/j.resconrec.2016.08.025

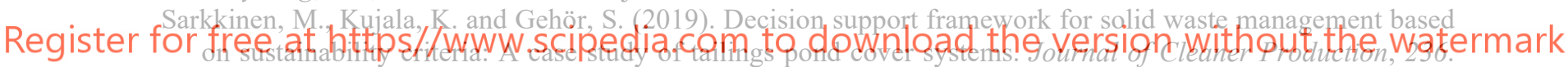
doi: 10.1016/j.jclepro.2019.07.058

Svajlenka, J. and Kozlovska, M. (2018). Houses Based on Wood as an Ecological and Sustainable Housing Alternative-Case Study. Sustainability (Switzerland), 10(5). doi: 10.3390/su10051502

Zhang, H., Peng, Y., Tian, G., Wang, D. and Xie, P. (2017). Green material selection for sustainability: A hybrid MCDM approach. PLOS ONE, 12(5). doi: 10.1371/journal.pone.0177578

Zheng, X., Easa, S. M., Yang, Z., Ji, T. and Jiang, Z. (2019). Life-cycle sustainability assessment of pavement maintenance alternatives: Methodology and case study. Journal of Cleaner Production, 213, 659-672. doi: 10.1016/j.jclepro.2018.12.227 